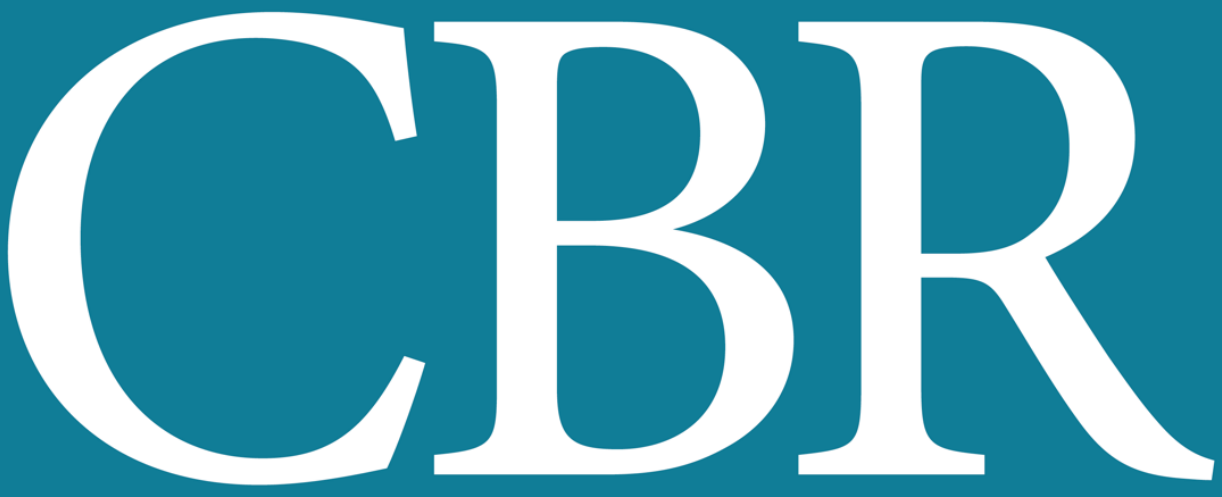

INTERNATIONAL JOURNAL OF CANCER AND BIOMEDICAL RESEARCH

https://jcbr.journals.ekb.eg

Editor-in-chief

Prof. Mohamed Labib Salem, PhD

Biochemical Oncology for Personalized and Precision Medicine

Nadia Hamdy 


\section{International Journal of Cancer \& Biomedical Research (IJCBR) https://jcbr.journals.ekb.eg}

IJCBR is an Int. journal published by the Egyptian Society of Cancer Research (EACR, established in 2014, http://eacr.tanta.edu.eg) and sponsored by the Egyptian Knowledge Bank (EKB: www.ekb.eg).

IJCBR has been approved by the Supreme Council of Universities, Egypt with score 7 (http://egjournal.scu.eg). The journl is cited by google scholar and registered by Publons (https://publons.com). The journal has recently been evaluated in 2020 by Nature Springer with a good standing.

\section{Scope of IJCBR}

- Drug discovery from natural and synthetic resources

- BioMedical applications of nanotehnology

- Sem cell biology and its application

- Basic and applied biotechnology

- Inflammation and autoimmune diseases

- In slico models and bioinformatics

- In vitro and In vivo preclinical animal models

- Cellular and molecular cancer biology

- Cancer Immunology and Immunotherapy

- New methods for prediction, early detection, diagnosis prognosis and treatment of dieases.

- Immunology in health and dieases

- Anti-microbial defense mechanisms

- Cellular and molecular physhiology and pahthology of diseases

\section{IJCBR Editor,}

Prof. Mohamed Labib Salem, PhD

Professor of Immunology

Faculty of Science, Tanta Universiy, Egypt 


\title{
Biochemical Oncology for Personalized and Precision Medicine
}

\author{
Nadia Hamdy \\ Biochemistry and Molecular Biology Department, Faculty of Pharmacy, Ain Shams University, Cairo, Egypt
}

\section{III}

\section{ABSTRACT}

Still cancer treatment is a major challenge to Health Care Sustainability (Egypt Vision 2030). Chemotherapy normo-toxicity as well as multidrug cancer cell resistance raise the debate of "Die Another Day" or "Die Another Way". This mandates identification of chemo-preventive and/or chemo therapeutic agent(s) that can target most, if not all, "Cancer Hallmarks", translated into "Drug-Resistance Hallmarks", in a way that regulates the proliferation of unwanted cancer cells, with minimal side effects or multi-organ toxicity, with prolonged overall survival.

This can be achieved via cutting-edge research such as site-specific delivery cargos, specific rocket targeting using nanotechnology, the use of natural compounds and drug repurposing. This would achieve a green environment in drug design and development, which is the central focus of "Biochemical Oncology Field" for cancer management. This includes cell signaling pathways, maintaining a balance between cell proliferation and death, stemness of cancer cells, epithelial-mesenchymal transition, dysregulation of the cell cycle, tyrosine kinase growth factor signaling pathways. Understanding of these biochemical signatures in cancer would open a new avenue to control altered drug metabolism, featured by "Tumor MicroEnvironment".

Keeping in mind, first, that no single drug can target all cancer hallmarks, affect drug metabolism, drug resistance. Second, no single treatment can target all cancer types or can fit all cancer patients or even one patient with a variety of concomitant diseases or different environmental stressors! Hence, the design and production of chemo-preventive agents acting on these particular molecular targets are of great interest for cancer treatment personalization and precision medicine (Figure 1).

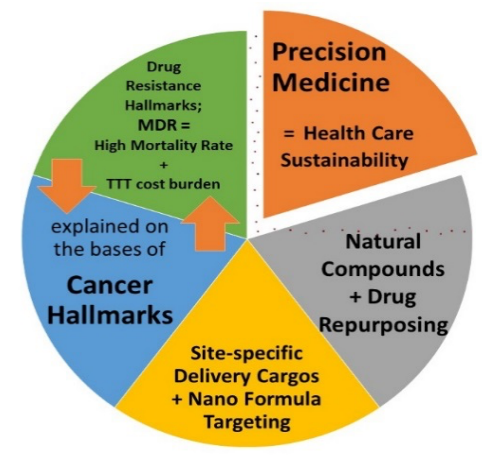

Figure 1. A sketch suggesting how biochemical oncology can target different hallmarks of cancer microenvironment

\section{ARTICLE INFO}

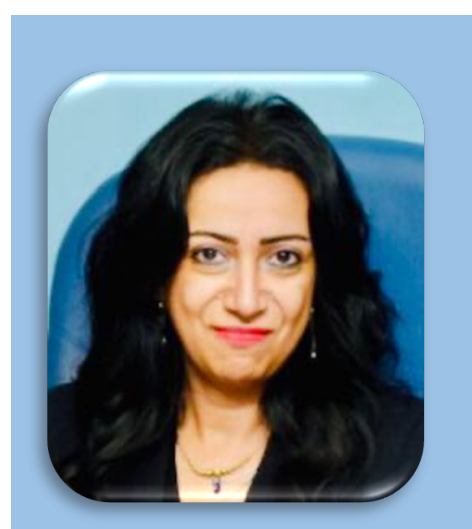

Article history

Received: March 26, 2021

Revised: March 26, 2021

Accepted: March 27, 2021

Correspondence to: Prof. Nadia Hamdy, Ph.D.

Biochemistry and Molecular Biology Department,

Faculty of Pharmacy, Ain Shams University, Cairo, Egypt.

Tel. +201005198788

Email:

nadia_hamdy@pharma.asu.edu.eg 


\section{Egyptian Association for Cancer Research (EACR)}

http://eacr.tanta.edu.eg/

EACR is an NGO society that was declared by the Ministry of Social Solidarity (Egypt) No. 1938 in 19/11/2014 based on the initiative of Prof. Mohamed Labib Salem, the current Chairman of EACR. EACR aims primarily to assist researchers, in particular young researchers in the field of cancer research through workshops, seminars and conferences. Its first international annual conference entitled "Anti-Cancer Drug Discovery" was successfully organized in April 2019 (http://acdd.tanta.edu.eg). Additionally, EACR aims to raise the awareness of the society about the importance of scientific research in the field of cancer research in prediction, early diagnosis and treatment of cancer. EACR is also keen to outreach the scientific community with periodicals and news on cancer research including peer-reviewed scientific journals for the publication of cutting-edge research. The official scientific journal of EACR is "International Journal of Cancer and biomedical Research (IJCBR: https://jcbr.journals.ekb.eg) was successfully issued in 2017 and has been sponsored by the Egyptian Knowledge Bank (EKB: www.ekb.eg).

\section{EACR Chairman,}

Prof. Mohamed Labib Salem, PhD

Professor of Immunology

Faculty of Science, Tanta Universiy, Egypt 


\section{Editor-in-Chief}

Mohamed Labib Salem, PhD

Tanta University, Egypt

\section{Managing Editor}

Nehal Elmashad, MD

Tanta University, Egypt

Nabil Mohy Eldin, PhD

Kafrelsheikh University, Egypt

Doaa Al-Ghareeb, PhD

Alexandria University, Egypt

Abdel-Aziz Zidan, PhD

Damanhour University, Egypt

Wesam Meshrif, PhD

Tanta University, Egypt

Rasha Eraky, MD

Tanta University, Egypt

\section{Associate Editor}

Hesham Tawfik

Tanta University, Egypt

Mostafa El-Sheekh

Tanta University, Egypt

Yousry Albolkiny, PhD

Tanta University, Egypt

Gamal Badr

Assuit University, Egypt

Elsayed Salim

Tanta University, Egypt

Essam Elshiekh

Tanta Cancer Center, Egypt

\section{Editorial Board}

\author{
Alberto Montero \\ Taussig Cancer Center, \\ Cleveland, USA \\ Marcela Diaz \\ Cleveland Clinic Foundation, USA \\ Yi Zhang \\ Zhengzhou University, China \\ Shengdian Wang \\ Chinese Academy of Sciences, \\ China \\ Faris Alenzi \\ Prince Sattam bin Abdulaziz \\ University, KSA \\ Mark Robunstein \\ Medical University of South \\ Carolina, USA \\ Mamdooh Ghoneum, DSc \\ Charles Drew University of \\ Medicine \& Science, USA
}

Natarajan Muthusamy, DVM

The Ohio State University, USA

Hideki Kasuya MD, PhD,

FACS

Nagoya University, Japan

Sherif El-Khamisy, MD

Sheffield University, UK

Mohamed Abou-El-Enein,

MD

Charité Universitätsmedizin

Berlin, Germany

Alaa Eldin Almostafa, MD

McGill University, Canada

\section{Amr Amin}

United Arab Emirates

University, UAE

AbdelRahman Zekri

National Cancer Institute, Egypt

Mohamed Attia, MD

Tanta University, Egypt

Mohamed Elshanshory, MD

Tanta University, Egypt

Hussein Khamis

Alexandria University, Egypt

Magdy Mahfouz

Kafr Elsheikh University, Egypt

Ehab Elbedewey

Tanta University, Egypt

Abeer Badr

Cairo University, Egypt

Nadia Hamdy, PharmD

Ain Shams University, Egypt

Ibrahim El-Sayed

Menoufia University, Egypt

Tarek Aboul-Fadl, PharmD

Assiut University, Egypt

Mohamed Noureldin

Banaha University, Egypt

Haiam Abou Elela

National Institute of

Oceanography and Fisherie,

Egypt

Sameh Ali, MD

Nationa Liver Institute, Egypt

Maha EL-Demellawi

City for Scientific Research \&

Technology Applications, Egypt

Desouky A Abd-El-Haleem

City for Scientific Research \&

Technology Applications, Egypt
Ashraf Tabll

National Research Center, Egypt

Wael Lotfy, MD

Alexandria University, Egypt

Olfat Gadallah, MD

Tanta University, Egypt

Nahla Shoukry

Suez University, Egypt

Medhat Eldenary

Tanta University, Egypt

Nagla Sarhan, MD

Tanta University, Egypt

Naglaa Fathy, MD

Zagazik University, Egypt

Azza Hasan Mohamed Menufia University, Egypt

Nanees Gamal Eldin

Tanta University, Egypt

Mohamed Mansour, UK

Sabbah Hammoury

Alexandria Ayadi Almostaqbal

Oncology Hospital, Egypt

Nehal Aboulfotoh

Zewail City for Science and

Technology, Cairo, Egypt

Amir Elkhami

Galaxo, San Francisco, USA

Rabab Khairat

National Research Center,

Giza, Egypt

Ahmed Alzohairy

Zagazi University, Egypt

Wgady Khalil

National Research Center, Egypt

Sayed Bakry

Alazhar University, Egypt

Mohamed Ghanem, MD

Kafr Elshikh University, Egypt

Mohamed Salama, MD

Mansoura University, Egypt

Mona Marie, MD

Alexandria University, Egypt

\section{For more information, contact}

Hamdi Kandil

Tanta University, Egypt

Email: ljcbr100@gmail.com 